\title{
IMPACT OF ADMINISTRATIVE BARRIERS ON THE SUCCESS OF EU PROJECTS
}

\author{
Matúš Drotár ${ }^{1}$ \\ Miroslav Šipikal ${ }^{2}$
}

DOI: https://doi.org/10.31410/LIMEN.S.P.2019.37

\begin{abstract}
Support by means of projects supported by the EU Cohesion Policy is, in less developed regions of the EU, often a key source of financing of development. From this viewpoint, it is very important to ensure its efficient and effect use. A frequent problem in the effort to achieve such use is administrative barriers. The purpose of this article is to identify the effect of such barriers in the process of filing applications for the support in the case of Slovak Republic. The survey was carried out in the form of questionnaire among applicants for the support. The survey has shown that such barriers are perceived as a significant issue but do not pose a barrier leading to selection of other projects just because the applicants with good projects are not able to cope with such obstacles.
\end{abstract}

Keywords: Cohesion policy, Projects burden, Slovak Republic, Programming period.

\section{INTRODUCTION}

E uropean structural and investment funds are EU tools intended for helping regions, in particular, the less developed ones. Importance of this financial aid for the Slovak Republic is, however, expressed not only in the absolute amount of funds but also by their share in the total amount of public investments. In the Slovak Republic, more than $80 \%$ of all public investments are funded by the EU funds. It is undoubtedly a high figure (one of the highest ones in the entire $\mathrm{EU})$, which expresses a significant dependence of the national economy in this kind of aid.

A large part of the support is carried out by means of individual projects. The success rate of the project, by means of which operational programmes and objectives of the Cohesion Policy are implemented, is closely related to access and use of such funds by different target groups for which they are intended. We mean, above all, applicants and beneficiaries that are local government authorities, businesses, NGOs and state administration authorities, which prepare, submit and implement projects funded by EU funds. The success rate of projects depends on several factors, whereas, one of the important factors is administrative restrictions. Such restrictions can occur at several levels. Some studies deal with administrative restrictions on the part of providers or recipients of support (Milio, 2007; Lorvi 2013), where they point out at insufficient administrative capacities, both quantitative and qualitative. Another issue is the necessity to return funds as a result of administrative errors (EDA, 2018), which can be even threatening to existence for certain applicants, especially from among NGOs, and discourages them from further submitting projects or they deem it too bureaucratic, especially if they achieve their set goals of projects and corrections result from legislative and/or administrative requirements.

Another frequently mentioned factor is legislative and administrative restriction or obstacles perceived by applicants for projects. A frequent reservation is a useless quantity of documents neces-

\footnotetext{
1 Comenius University, Šafárikovo nám. 6, 81000 Bratislava, Slovak Republic

2 University of Economics in Bratislava, Dolnozemská cesta 1, 85235 Bratislava, Slovak Republic
} 
sary to filing projects and extensive documentation for submitting projects (Kostálová et. al, 2015; Zimmermannová and Brown, 2015). Several studies and reports point out at the need to simplify certain processes, focus more on outputs than on the formal administrative control or adjustment of the legislation to the needs of implementation of development projects (Barca, 2009; CKO, 2013).

The purpose of the article is to analyse how the administrative burden is perceived by applicants and beneficiaries of aid in Slovakia and if the legislative and administrative burden have influence on the success of projects in the stage of their preparation.

\section{ADMINISTRATIVE BURDEN IN SLOVAK REPUBLIC}

Preparation of each programming period and the process of setting rules for implementation of EU funds includes intensive communication of the Member State with EU authorities (in particular, with the European Commission). The first official step is the preparation of legislative measures by which the European Commission will introduce its vision and forms of implementation of the Cohesion Policy. However, a relevant factor for a Member State is a more particular view or evaluation of its strengths and weaknesses, which are defined, with regard to implementation of EU funds, as presented by the European Commission, in the so-called Position Paper (EC, 2012). In respect to the Slovak Republic, this document was adopted in 2012, thus, two years prior to the official "launch" of Programming Period 2014-2020. Besides evaluation of different fields of the national economy, this document also focused on the field of administrative difficulty and its unification in the preceding Programming Period 2007-2013.

The fact that the European Commission pays attention to the administrative burden is also reflected in the fact that the Position Paper contains a separate chapter on this matter. Thus, the European Commission put the administrative difficulty of the very process of implementation to the level of other key matters, such as solutions for road and rail infrastructure, environment, unemployment, education and research and innovations. In the Position Paper, the European Commission defined, as one of its main recommendations for reducing administrative burden, the need to simplify the process of projects approval, clear setting of implementation rules and their publication sufficiently in advance, application of the so called simplified cost options, electronic data exchange and regular assessments of the administrative burden for applicants. Regarding the administrative burden reduction, similarly to other policies, the legislation of the EU for Programming Period 2014-2020 introduced several innovations and improvements. One of key measures was introduction of mandatory electronic communication between state authorities and beneficiaries before the end of 2015. It was the system of called mandatory eCohesion coined in the General Regulation (EU) No 1303/2013 of the European Parliament and the Council, in particular in Article 122(3), in the sense of which "Member States shall ensure that no later than 31 December 2015, all exchanges of information between beneficiaries and a managing authority, a certifying authority, an audit authority and intermediate bodies can be carried out by means of electronic data exchange systems". EU authorities expected this obligation to not only simplify the entire process of implementation but also to increase the level of transparency that is directly assumed by the "contactless" relation between applicants and state authorities. From among other simplifications, we can mention extended use of the so-called simplified cost options. It means that expenditure in implemented projects are reported only in the form of a flat rate amount without the need to report actual accounting documents. It is also necessary to not mention another innovation brought about by the new legislation for Programming Period 2014-2020, which is the direct use of EU funds from the so-called technical assistance for the purposes of simplifying 
processes on the part of applicants and beneficiaries. Also, in this way, the European Commission wanted to point out at the necessity to deal with the administrative burden at the level of Member States, whereas it is possible to use money from EU funds directly.

\section{SLOVAK MEASURES IN THE FIELD OF REDUCING ADMINISTRATIVE BURDEN}

The place of the first summarisation of measures aimed at reducing the administrative burden in Programming Period 2014-2020 is the Partnership Agreement (2014). It is a document of strategic nature in which member states specify main direction and areas of support from the EU funds and it is subject to approval by the EU authorities after being submitted by the relevant Member State. The document for the Slovak Republic was approved in 2014; besides different sectoral areas supported by the EU funds, it also defined specific measures aimed at reducing the administrative burden of the process of their implementation.

Particular measures the Slovak Republic intended to introduce in order to reduce the administrative burden were defined in Chapter 2.6 of the Partnership Agreement. Among the most important ones, let us mention introduction of aforementioned principles of eCohesion, training of administrative capacities of state authorities, extension of possibilities for the use of simplified cost options, establishment of a network of information and consultancy centres and measures aimed at simplifying the public procurement. As we can see, these are measures by means of which the Slovak Republic reflected, above all, recommendations from the Position Paper. In any case, it is possible to say that the measures in questions had the potential to ease access of applicants to the EU funds or ease implementation of already approved projects. Besides defining different measures, it is necessary, in our opinion, to also analyse the extent of their deployment. Regarding these measures, we can conclude, after an analysis, that most of them have been implemented by the Slovak Republic. Principles of eCohesion were fully implemented, by the specified deadline, to the electronic system ITMS 2014+, which enables fully electronic communication between beneficiaries and managing authorities. The system even goes further that imposed by the European legislation as it enables, beyond its framework, to use the functionality of fully electronic submitting of projects by means of accounts set up in ITMS 2014+. In respect to increasing the awareness of possibilities for acquiring EU funds, let us mention establishment of the network of so-called Information and Consultancy Centres. It is a system of 7 centres set up in premises of regional government authorities (with the exception of the Bratislava self-governing region), which are ready to provide free information about possibilities of acquiring funds or assist applicants with preparation of projects. It is a unique project funded from the technical assistance that brought the possibility of acquiring EU funds closer to citizens in regions. The system of simplified cost options was fully incorporated to the national methodology (so-called System for Management of European Structural and Investment Funds); template forms for public procurement were issued by the Public Procurement Office and, equally, a uniform system of trainings for administrative capacities at managing authorities was developed at the Office of the Government of the Slovak Republic.

\section{METHODOLOGY}

The survey was carried out in 2018, anonymously, by the Office of the Deputy Prime Minister of the Slovak Republic for Investments and Informatization and then sent to all applicants for the NFC from the EU funds under coordination of one of authors of the article. Altogether, 906 
responses were received, which means a high rate of return at the level of $45.05 \%$ of all applicants and beneficiaries in Programming Period 2014 - 2020 at that time.

Most respondents were from Banská Bystrica, Nitra and Košice regions (18\%, 16\% and 15\%), followed by Prešov, Bratislava and Žilina regions (11\% each) and Trnava and Trenčín (9\% and $8 \%$ ). The legal form of respondents that provided answers to questions also reflected the legal form of most frequent applicants of beneficiaries of the EU funds. Majority of responses in our questionnaire survey came from representatives of municipalities (58\% of all responses), followed by the business sector (15\%), state budgetary agencies $(9 \%)$, regional government authorities or their agencies (5\%), NGOs (4\%) and the academic sector (3\%). There was also equal distribution of operational programmes, in which different respondents had experience. Due to the fact that most responses came from the local government authorities, majority of answers concerned projects in operational programmes primarily intended for the needs of the local government. In particular, OP Quality of Environment - 22\%, Rural Development Programme $-20 \%$ and Integrated Regional Operational Programme - $18 \%$. Anyway, each of the 11 operational programmes implemented in Programming Period 2014-2020 was represented by responses.

In the second half of the survey, we analysed differences between those that got funding for their projects and those that did not. From the sample, we removed applicants with multiple projects that receive funding for some projects and were refused for other ones. Such sample would then not be statistically relevant from the viewpoint of more detailed characteristics such as region or size.

\section{SURVEY RESULTS}

When assessing the administrative burden, we also reviewed if it is perceived in a different way by applicants that received the funding and those that did not. There was a statistically relevant difference only for processing annexes to applications; the difference in perceiving filling in applications and the use of public procurement procedures was only minor and statistically not relevant worse compared to successful applicants. It indicates that although the administrative burden is perceived considerably negatively, probably it will not lead to not supporting good projects because of failure on the part applications to cope with the administrative burden. More detailed outcomes are provided in Table 1 . A statistically more relevant difference only occurred in the preparation of annexes to applications.

Table 1. Average assessment of the administrative burden of certain processes by applicants

\begin{tabular}{|l|c|c|c|}
\hline Activity & Average yes & Average no & $\begin{array}{c}\text { Pearson } \\
\text { Chi Quadrate Test }\end{array}$ \\
\hline $\begin{array}{l}\text { Performance of public procurement } \\
\text { procedures }\end{array}$ & 4.017588 & 4.023026 & 0.105 \\
\hline $\begin{array}{l}\text { Preparation and filling in applications for } \\
\text { the NFC }\end{array}$ & 3.405276 & 3.449231 & 0.025 \\
\hline $\begin{array}{l}\text { Preparation of mandatory annexes to } \\
\text { applications for the NFC }\end{array}$ & 3.32 & 3.555882 & 0.000 \\
\hline
\end{tabular}

Source: outputs of the survey. Yes - applicants whose projects were supported, no - applicants whose projects were not supported 
A bigger difference can be observed in answers to questions concerning availability of information, where the higher share of unsuccessful applicants indicated lack of such information. Results can be seen in Table 2 . On the contrary, it indicates that the very perception of the administrative burden can be partially caused by lack of information. Applicants that do not have clear and sufficiently communicated information in advance, can then, in the final stage of the project, perceive the pressure caused by lack of information as the administrative burden.

Table 2. Assessment of availability and quality of necessary information concerning the use of the non-repayable financial contribution from EU funds in the Slovak Republic

\begin{tabular}{|c|c|c|c|c|}
\cline { 2 - 5 } \multicolumn{1}{c|}{} & Insufficient & Rather insufficient & Rather sufficient & Sufficient \\
\hline Yes & 8 & 79 & 198 & 150 \\
\hline No & 31 & 76 & 142 & 95 \\
\hline
\end{tabular}

Source: outputs of the survey.

When we look at the differences in perception of the administrative burden by different groups, we did not identify differences in the perception of the administrative burden by different groups, we did not identify any significant difference based on the place of operation of applicants (regional dimension) or from the viewpoint of the size of applicants. However, the sample in this case is not representative and it is not possible to talk about statistically relevant difference. If we look at certain differences from the viewpoint of the breakdown into the public and private sector, results are shown in Tables 3 a 4. The most important difference in the perception of the public procurement (Table 3) among successful applicants was in the private sector. This sector does not always have much experience with implementation of the public procurement procedures fir to the fact that, with the exception of the projects, I tis not bound by any rules in purchases.

Table 3. Average assessment of the administrative burden related to the public procurement procedures by applicants

\begin{tabular}{|l|c|c|}
\cline { 2 - 3 } \multicolumn{1}{c|}{} & Yes & No \\
\hline Public sector - central government & 4.02 & 4.333333 \\
\hline Public sector - local and regional government & 4.19863 & 4.221239 \\
\hline Private sector & 3.957447 & 4.173077 \\
\hline
\end{tabular}

Source: outputs of the survey

From the viewpoint of annexes to the application (see Table 4), we can see a more distinct difference between successful and unsuccessful applicants only in the private sector, we can also see that there are not significant differences between the private and public sector.

Table 4. Average assessment of the administrative burden related to the preparation of mandatory annexes by applicants

\begin{tabular}{|l|c|c|}
\cline { 2 - 3 } \multicolumn{1}{c|}{} & Yes & No \\
\hline Public sector - central government & 3.345455 & 3.6 \\
\hline Public sector - local and regional government & 3.487085 & 3.458537 \\
\hline Private sector & 3.192982 & 3.444444 \\
\hline
\end{tabular}

Source: outputs of the survey

After comparing the responses to responses focused on the implementation of projects, it is possible to see more distinct differences between the private and public sector. It indicates that this sector can see the biggest problems in the implementation of projects themselves, not in applying for the support. 


\section{CONCLUSION}

Administrative burden represents a significant problem in the perception of how the support from the European Structural and Investment Funds works. Results show that this perception is not changing in the course of time even though a lot of measures have been implemented in order to reduce such perception. There may be several explanations for it. One possibility is that also the processes declared as reduction of the difficulty can mean as its increase for certain applicants. An example of that is electronization of applications that can be viewed by people with lower level of ICT use or knowledge as reduction of the comfort in submitting projects. The second possible explanation is a shift in the perception of the administrative burden. The entire public and private sector have moved significantly forward in this direction in the past years (electronic extracts, less need to go to offices, mobile applications, etc.), so the reduction of the burden, as it was "slower" than in other sectors, could have led to negative perception by applicants.

At the same time, we pointed out at the fact that there are no significant differences between the perception of the burden between successful and non-successful applicants, as well as between public and private sector. Thus, results rather indicate the need for general activities aimed at improving the situation not the need for specific measures for certain target groups or regions that perceived the burden significantly worse.

\section{ACKNOWLEDGMENT}

Part of the contribution in this article was supported by VEGA, grant no. 1/0605/19.

\section{REFERENCES}

Barca, F. (2009). Agenda for a reformed cohesion policy. Brussels: European Communities.

CKO. (2013). Zhodnotenie administratívnej zát’aže na strane žiadatel'ov a prijímatel'ov v procese implementácie pomoci $\mathrm{z}$ fondov EÚ v programovom období 2007-2013 (Assessment of the administrative burden by applicants and beneficiaries in the process of implementation of EU funds in Programming Period 2007-2013) http://www.nsrr.sk/sk/hodnotenie/programove-obdobie-2007---2013/ [quoted on 7 July 2019].

CKO. (2018). Zhodnotenie administratívnej zátaže na strane žiadatel'ov a prijímatel'ov v procese implementácie pomoci $\mathrm{z}$ fondov EÚ v programovom období 2007-2013 (Assessment of the administrative burden by applicants and beneficiaries in the process of implementation of EU funds in Programming Period 2007-2013)

https://www.partnerskadohoda.gov.sk/data/files/1882_sprava-priesku_admin_zataze.pdf [accessed on 7 July 20019].

EC. (2012). Pozičný dokument Európskej komisie k Partnerskej dohode a programom SR na roky 2014 - 2020 (Position Paper of the European Commission on the Partnership Agreement and programmes of the Slovak Republic for 2014-202), http://www.nsrr.sk/sk/programove-obdobie-2014---2020/pozicny-dokument-europskej-komisie-k-partnerskej-dohode-a-programom-sr-na-roky-2014---2020/ [accessed on 7 July 2019].

European Court of Auditors (ECA). (2018). Activity Report 2018, http://publications.europa.eu/ webpub/eca/annual-activity-report-2018/sk/\#chapter2 [accessed on 7 July 2019].

Kostalova, J., Tetrevova, L., \& Patak, M. (2015). The system of support for projects co-financed by EU funds in the Czech Republic. Transylvanian Review of Administrative Sciences, 11(45), 97-115. 
Lorvi, K. (2013). Unpacking administrative capacity for the management of EU structural funds in small and large municipalities: the Estonian case. Administrative Culture, 14(1), 98-124.

Milio, S. (2007). Can administrative capacity explain differences in regional performances? Evidence from structural funds implementation in southern Italy. Regional studies, 41(4), 429-442.

Sipikal, M. (2015). Political and Administrative Barriers of Cohesion Policy Implementation in Slovakia. International Journal of Social Sciences, 4(2), 39-48.

Zimmermannová, L., \& Brown, L. (2012). Problematika čerpání prostředků ze strukturálních fondů v České republice: překážky limitující plynulé čerpání z fondů. (Spending structural funds in the Czech Republic) University of Economics. [online]. [accessed on 23 March 2015]. Available on: http://nf.vse.cz/wpcontent/uploads/fewpp_article-cerpani-SF-zimmermannova-brown. pdf.

Regulation (EU) No 1303/2013 of the European Parliament and of the Council of 17 December 2013 laying down common provisions on the European Regional Development Fund, the European Social Fund, the Cohesion Fund, the European Agricultural Fund for Rural Development and the European Maritime and Fisheries Fund and laying down general provisions on the European Regional Development Fund, the European Social Fund, the Cohesion Fund and the European Maritime and Fisheries Fund and repealing Council Regulation (EC) No 1083/2006

Partnership Agreement for 2014-2020. (2014). http://www.partnerskadohoda.gov.sk/hlavna-stranka-pd/ [accessed on 7 July 2019]. 